\title{
Student Support System in Virtual Learning Environment for Medical Education: McKenna Content Analysis Method
}

Zohrehsadat Mirmoghtadaie

Shahid Beheshti University

Mojgan Mohammadimehr ( $\triangle$ mojganmehr20@yahoo.com )

Aja University of Medical Sciences https://orcid.org/0000-0002-9210-0687

\section{Research article}

Keywords: Student support service, Concept Analysis, virtual learning

Posted Date: August 20th, 2020

DOI: https://doi.org/10.21203/rs.3.rs-55477/v1

License: (c) (1) This work is licensed under a Creative Commons Attribution 4.0 International License.

Read Full License 


\section{Abstract}

Background: Student support services are a broad and important concept in education, each of which is related to a specific set of hypotheses related to the subject. This lack of theoretical and conceptual ambiguity has led to poor understanding and communication between researchers and policymakers and problems in comparing studies in different fields. The purpose of this study is to explain the student support system in virtual learning environment for medical education.

Methods: This study was a qualitative research. An extensive search in scientific databases was carried out based on predetermined strategies, and 53 documents were reviewed from 1996 until 2019. Data were analyzed based on Hugh McKenna's nine-step approach.

Results: According to the literature review, determining the support services of students in virtual learning, providing academic and non-academic services is the responsibility of students' cognitive, emotional and social needs. These services lead to greater student participation in the process of self-learning and academic achievement, which is done at three levels: (pre-program, learning process and post-graduate support services). Student support services were categorized into conceptual areas (level, dimensions, and purpose) and the relationship between these conceptual areas was identified.

Conclusions: Based on the findings of this study, student support services in virtual learning can be divided into two categories: academic and non-academic with relevant subcomponents. It is recommended that educators and policy makers use these results to facilitate student support for different types of virtual learning.

\section{Background}

The Internet provides the basis for new learning environments called "virtual learning"[1]. The world is becoming more interconnected and complex. Online learning is going through a period of rapid and unprecedented change. The following e-Learning trends and predictions for 2020 will help you to get ready for this space [2]. Medical education is a process that continues throughout the life of medical students. The development of information has made medical science knowledge constantly evolving. As a result, the knowledge and skills gained at the end of academic education cannot guarantee the skills needed during the individual's lifetime. Therefore, medical students need to acquire more skills during education such as self-directed learning in order to lifelong learning [3].

According to the benefits of virtual education and its effective impact in medical education, it seems inevitable to incorporate it into the current curriculum, so that conventional methods of teaching are a combination of traditional education and e-learning $[4,5]$. Blended learning is an approach to education that combines online educational materials and opportunities for interaction online with traditional placebased classroom methods. By using a combination of digital instruction and one-on-one face time, students can work on their own with new concepts that free teachers up to circulate and support individual students who may need individualized attention. "Rather than playing to the lowest common 
denominator - as they would in a traditional classroom - teachers can now streamline their instruction to help all students reach their full potential. Working in ablended learning environment requires high flexibility [6].

The width and depth of distance learning depend on the objectives and prospects of this type of education based on upstream policies [7]. For many reasons, such as the complexity of this learning environment, all thelearners cannot perform this responsibility as fully as possible and some of them do not achieve success and satisfaction due to the lack of requirements management [8]. Student support is a generic term used for a wide range of services and offers by institutions to help studentsacquire and develop learning objectives and achieve knowledge, attitude and skills [9].

Support services are a very important element for all educational institutions; however, these services are much more essential in e-learning than face-to-face. One of the most important reasons is that teachers and students are not in a physical environment and distance learning sessions usually require more interpersonal interactions than group interactions [10].

Some learners feel lonely. In addition, some studentsstop attending classor drop out of collegedue to the lack of self-management skills, motivation and a sense of belonging to theirinstitution. To overcome these problems, student support services have emerged as an important element of the distance education system [11]. New courses, although emphasizing active learners, support systems facilitate the learning process through learning tools and services $[12,13]$. The development of an organization-based support system is accomplished through a number of techniques. The main focus of this support system is on the satisfaction and facilitation of learners [13]. There is a lot of research showing that comprehensive support for education can lead to academic well-being. Academic well-being is the attitude of students to education. This attitude has meaning in four dimensions: the general attitude to the academic life, the attitude to the teacher, the attitude to the peers and the attitude to the organizational structure of colleges [14]. In many studies, the impact of support service on student's wellbeing has been demonstrated, but what are the dimensions and components of the concept of support in blended learning? There is very low research in this field and only has focused onwhen the student support service should be activated [15]. There is no specific support mechanism in blended learning, soln this study, we have tried to use concept analysis to identify the dimensions of student service and to refine basic conceptual components in order to provide a clear and practical definition.

\section{Methods}

\section{1-Search strategy concept analysis}

The search strategy of this concept analysis included a protocol-driven search. Original articles, as well as theoretical and conceptual articles, were consulted. We looked at peer-reviewed papers in all of the fields.Nine databases were searched (ProQuest, ERIC, Google Scholar, Science Direct, Scopus, and Medline, ISI, ISC and web of science)with the following keywords entered:Support system, Support 
service, Education support system, Training Support, Practical or emotional support system, Academic support, Learner support, Student support service, Smart support service,E- support, Faculty support system. The search terms above were combined with the following terms:Distance learning, E-learning, Blended learning, Virtual learning, Distance education, Computer enhanced learning, Online education, Online class.

\section{2-Eligibility criteria}

In the review of literature, 1872 related articles available on the databases from 1996 until 2019 were found. We, therefore, had to develop a data management strategy; the search was limited to articles that listed the search terms in their title. At first, abstracts of the study articles were selected, and articles that described the concept or provided evidence related to the concept were selected for the full-text study. No further assessment of the validity or quality of the full text was conducted. All the definitions were screened by two peers from the same research unit who evaluated the definitions' appropriateness. Finally, 53 documents were reviewed. (Fig. 1)

\section{3-Concept analysis}

Conceptual analysis is a precise process that attempts to identify, clarify and explain an abstract concept and to distinguish it from similar concepts [16-19]. There are different approaches, in this study, Hugh McKenna approach is used for concept analysis [17]. The analysis was comprised of the 9 steps shown in Fig. 2.

\section{Results}

\section{1-Definitions}

Support service is a very complex concept: it can be approached from several perspectives (the students, teachers or the education system) that lead to different dimensions. There was nonobvious distinction between "Academic support, Learner support, Faculty support system, Education support system, Esupport, Training Support, Smart support service, Support service, emotional support system"in context from reliable sources. At this stage reference phrases are also known as primary concept structures were extracted from the existing documentation, i.e. the exact sentences were quoted. In the next stage, we introduced our interpretation of primary phrases. Then we introduced our interpretation of primary phrases in documentations as the potential attributes that define the concept of support service. Some attributes of concept repeated frequently. This stage was performed with high accuracy and the specific attributes of the concept were extracted.

Therefore, student supportive service in blended learning is to provide academic and non-academic services to the responsivity of the cognitive, affective, and social needs of students. These services lead 
to further engagement the student in the process of self-learning and academic achievement, and are performed at three levels: Pre-program, learning process and Post-graduation support services. Based on resources that discussed support service, the main components of this concept were determined as follows: Supportive Service's Levels, Supportive Service's Dimensions, and Supportive Service's purposes (Fig. 3)

\section{Levels of Student Supportive Service}

The study of the texts showed that this field has three separate parts: Pre-program support services, thelearning process support services $\square$ and Post-graduation. 
Table 1

Levels of Student Supportive Service \& References

\section{Levels of Student Supportive References Service}

Pre-program support services $\quad$ - Kumtepe EG, Toprak E, Ozturk A, Buyukkose GT, Kilinc H, Menderis IA. 2003 [10]

- Floyd DL, Casey-Powell D. 2004[20]

- Gujjar, A.A., Naoreen, B. Chaudhry, A.H., 2010. [21]

- Chatpakkarattana T, Khlaisang J. 2012 [11]

- Jain P, Salooja M, Mythili G. 2016 [22]

- Sahoo PK.2018 [23]

The learning process support services

- Tait A. 2000 [24]

- Kumtepe EG, Toprak E, Ozturk A, Buyukkose GT, Kilinc H, Menderis IA. 2003 [10]

- LaPadula M. 2003 [25]

- Darojat O, Sunarsih D. 2014 [26]

- NurmukhametovN.a, TemirovaA.b, BekzhanovaT.2015 [27]

- Arko-Achemfuor. 2017 [9]

- Lu P, Luo L. 2017 [28]

- Sánchez-Elvira Paniagua A, Simpson O. 2018 [29]

Post-graduation support

- Floyd DL, Casey-Powell D. 2004 [20]

services

- Dey F, Cruzvergara CY. 2014 [30]

- Hayden SC, Ledwith KE. 2014 [31]

- Smith KK. 2014 [32]

- NurmukhametovN.a, TemirovaA.b, BekzhanovaT.2015 [27]

- Kamran Mir. 2016 [33]

- Kelkar D.2016 [34]

- Young M. 2019 [35]

\section{1-1-Pre- program student support services:}

Moreover, institutions in the education sector are expected to use information and communication technologies effectively in order to be successful in educational activities and programs. At this phase, 
entry requirements and all rules and regulations of the academic calendar will be announced. Theseltems illustrate the college's commitment to programs and facilitate decision making for students.

\section{1-2-learning process student support services:}

The development of a learning support service for distance learning during the academic yearsincludes:1) establishing and improving information media, 2) exploring learning strategies for learners and 3) Access to all digital resources. If support services are further developed, learning outcomes will show a clear improvement [36]. The support system has been described in two different ways:1. individual-oriented (interaction with the individual and his/her own learningsystems) and 2. Intrapersonal interactions (learner-learner, learner-instructor, learner-content-material/interface, etc.) that are both necessary during student life [10].

\section{1-3- Post-graduation student support services:}

During this phase, students need services to help them find the job opportunities. Student support services should be user-friendly and learner-centered $[$ however, delivering effective and efficient service has always been a major challenge for higher education Managers.

\section{2-Student Supportive Service Dimensions}

In the review of literature, student support services include two types: academic and non-academic services. Academic services are supervised by academic staff and are based on university decisions and are related to teaching and learning issues and problems. But non-academic services are centralized services that are not related to the teaching-learning process but improve learning conditions [15]. The following table shows the attributes of each dimension. 
Table 2

Dimensions of Student Supportive Service

\begin{tabular}{|c|c|c|}
\hline Dimensions & References & Attributes \\
\hline Academic Services & $\begin{array}{l}\text { Farajollahi,2010 } \\
\text { [37] } \\
\text { Lee,2013 [38] } \\
\text { Stewart,2013 [39] } \\
\text { Newberry,2013 [40] } \\
\text { Tamulienè,2014 } \\
\text { [15] }\end{array}$ & $\begin{array}{l}\text { A. Instructional Services } \\
\text { - Registration of Students } \\
\text { - Looking After the Admission } \\
\text { - Clear Cut Norms } \\
\text { - Preparation of Guidelines and Instructions } \\
\text { - Degree and Transcript Auditing } \\
\text { - Orientation Courses } \\
\text { - Academic Advising } \\
\text { - Course Offering \&Availability } \\
\text { - Online Representatives } \\
\text { - Learning Material Support } \\
\text { - Examination and Evaluation Services } \\
\text { B. Tutoring Services } \\
\text { - Ways of Communication\& Interaction } \\
\text { - Online Faculty Advising } \\
\text { - Assignment Help } \\
\text { - Networking } \\
\text { - Contact Tutoring } \\
\text { C. Technical Services } \\
\text { - Learning Management System } \\
\text { - Learning Content Management System } \\
\text { - Infrastructure \& Facilities } \\
\text { D. Library And Bookstore Services }\end{array}$ \\
\hline
\end{tabular}




\begin{tabular}{|lll|}
\hline Dimensions & References & Attributes \\
\hline $\begin{array}{l}\text { Non-Academic } \\
\text { Services }\end{array}$ & Pullan,2011 [41] & A. Counseling Services \\
& Hunte,2012 [42] & - Law Consultations \\
Noviyanti,208 [43] & - Academic Counselling \\
Gregori, 2018 [44] & - Health Consultations \\
Tuquero, 2011[45] & - Job Counselling \\
& B. General Services \\
& - Student Help Desk Support \\
& - Financial Support \\
& - Disability Services \\
& - Phone Numbers \\
& - Language Training \\
& - Information About Distance Learning \\
& Opportunities \\
& - Accommodation \\
& - Social Support Services \\
&
\end{tabular}

\section{3-Supportive Service purposes}

The purpose of student support is to increase graduation rates and to improve student retention rates. There is competition between institutions to give grants. They also provide opportunities for students to improve their academic performance by motivating students. Supporting and enhancing the student experience from the first contact through to becoming alumni is critical to success in higher education today for both the student and the institution. Student support and services contribute to the quality of their learning experience and their academic success. Ciobanu said:" The student services value needs greater recognition, support, and development in the interests of all students.

Student services contribute to the quality of students learning experience and their academic success, contribute as well at the university dropout rate decrease and to the increase in students' life diversity, encouraging and establishing an open method of making rational decisions and also resolving conflicts and prepare students for active involvement in society" [46]. 
Table 3

purposes of student Supportive Service

\begin{tabular}{ll} 
Definition(Purpose of Student Support Service) & References \\
\hline Responsibility to the cognitive, affective, and social needs of students & $\begin{array}{l}- \text { Nsamba \&Makoe, } \\
2017 \text { [47] }\end{array}$ \\
$\begin{array}{ll}\text { Scientific success and removal of situational, organizational and } \\
\text { information barriers }\end{array}$ & - Sewart, 1993 [48] \\
& - Potter, 1998 [49] \\
& - Brindley J.E, 2014 [50] \\
Student engagement in the learning process & - Rangara 2015 [51] \\
\hline
\end{tabular}

\section{Discussion}

Every day the higher education market is becoming more competitive. Many students are interested in online courses. To stay in the competition, they need to have special program institutions to support students online. Students are seeking to identify the best distance education program that can provide the most services in addition to the quality of education [53]. Student support is a general term used for a wide range of services provided by institutions to help students complete their learning objectives and their course [9]. Student support services are very important elements for all educational institutions, especially e-learning [10]. The development of an organization-based support system is accomplished through techniques. The main focus of this support system is on the satisfaction and facilitation of learners [13]. Wright describes that support for learners isan inevitable element in creating the effective learning experience for distance learning [54]. Thorpe also considers that support is the basis of an open learning system and can respond to the needs of the individual learning process [55]. In addition to studies focusing on the importance of learning support, Gorder noted the support of academic staff for the success of any distance education system [56].

Floyd also reported that educational support is to create a positive interaction environment between learners and staff [20]. Various studies have shown that in successful universities around the world, student support extends from pre-university to post-graduation [57-60]. Helping students to develop and complete a professional resume and advising on interview strategies is need. At some universities, such as Portland Community College, students can pass different job workshops, such as how to succeed in job interviews, decision making, and goal setting. Rio Salado College also provides an electronic selfassessment tool and provides information on the job market in various occupations [20].

Student support services are defined in two ways: academic and non-academic services. Academic services are performed by academic staff and are based on university decisions and are related to teaching and learning issues and problems $\square$ However, non-academic services are not related to academic topics but they provide the Suitable conditions for the student $[15,48,61]$. Students' needs play an 
important role in designing and improving educational systems. The development of a quality management system in higher education is based on the student's expectations will have as customers and evaluating their opinions, especially in the negative, can improve quality $[62,63]$. Student support services guarantee academic success. Student support services in the virtual environment are very necessary because in this space the student feels alone [64]. Teacher and student separation affect teaching and learning. A dynamic and active system helps students to not be isolated and decentralized. As a result, it prevents lower levels of motivation, interaction, and laziness [65]. If supportive strategies are not considered in an e-learning system, there will be a rapid decline and an increase in [66].

\section{Limitations}

First, the subdivision of dimensions was sometimes subjective and artificial. Secondly, we did not conduct a systematic evaluation of the quality of the included research articles. Thirdly the search was limited to articles that listed the search terms in their title. Finally, we only reviewed English articles.

\section{Conclusion}

Working in virtual education requires flexibility [7]. Some students leave online courses because they have low motivation and lack of self-management skills. To overcome all these problems, student support services have emerged for the effective and sustainable distance education system [11]. The institution should provide face-to-face and distance support services.

The student support system can encourage students and faculty in cyberspace [67]. All individuals and structural resources in the distance education system should be considered an integral part of support services. Student support services in this type of education can create positive conditions for the student. Unfortunately, evenexperienced virtual educational institutions are not paying attention to the student support system. Research in this area has been scant and has only focused on when the student support system should be activated [68]. No research has shown that supports is fit to the student's needs [15].

\section{Declarations}

\section{Acknowledgements}

This article is part of a research project approved by Iran Medical Affairs Strategic Research Center (970252). We appreciate all the professors who collaborated on this research.

\section{Authors' contributions}

Mirmoghtadaie was involved in data gathering, investigation, analysis, preparing the original draft of the manuscript. Mohammadimehr were involved in data gathering, methodology, investigation, project administration, supervision and reviewing and editing the manuscript. All authors have read and approved the manuscript. 


\section{Funding}

This research was supported by Iran Medical Affairs Strategic Research Center

\section{Availability of data and materials}

All data generated or analysed during this study are included in this published article.

\section{Conflict of Interest}

This research did not and did not have any conflicts of interest with any particular individual or organization.

\section{References}

1. Shieh C J, Yu L. A Study on Information Technology Integrated Guided Discovery Instruction towards Students' Learning Achievement and Learning Retention. Eurasia journal of mathematics, science \& technology education. 2016;12(4): 833-842.

2. Lopez-Catalan B, Bañuls VA. A Delphi-based approach for detecting key e-learning trends in postgraduate education: The Spanish case. Education \& Training.2017;59(6): 590-604.

3. Duffy FD, Holmboe ES. Self-assessment in lifelong learning and improving performance in practice: physician know thyself. JAMA. 2006;296(9): 1137-1139.

4. Frehywot S, Vovides Y, Talib Z, Mikhail N, Ross H, Wohltjen H, Bedada S, Korhumel K, Koumare A K, Scott J. E-learning in medical education in resource constrained low-and middle-income countries. Human resources for health. 2013;11(1): 1-15. https://doi.org/10.1186/1478-4491-11-4

5. Liu Q, Hu R, Zhan X, Yan W. Evaluation of Students' Satisfaction and Attitudes Toward Blended Learning in Medical Education: A Survey in Randomized Controlled Trial Course. Proceedings of the European Conference on e-Learning; 2014 Jan p679.

6. Wikipedia contributors. Blended learning. In Wikipedia, the Free Encyclopedia. Retrieved 19:00, [citd 2019 December 17]. available from: https://en.wikipedia .org/w/index.php? title = Blended_learning \& oldid $=930674805$

7. Lenar S, Artur F, Ullubi S, Nailya B. Problems and decision in the field of distance education. ProcediaSocial and Behavioral Sciences. 2014; 131:111-117.

8. Yukselturk E, Yildirim Z. Investigation of interaction, online support, course structure and flexibility as the contributing factors to students' satisfaction in an online certificate program. Journal of Educational Technology \& Society.2008; 11(4): 51-65.

9. Arko-Achemfuor Student support gaps in an open distance learning context. Issues in Educational Research. 2017;27(4): 658-676.

10. Kumtepe E G, Toprak E, Ozturk A, Buyukkose GT, Kilinc H, Menderis I A. Support Services in Open and Distance Education: An Integrated Model of Open Universities. 2003:114-123. Available: 
https://members.aect.org/pdf/Proceedings /proceedings 18/ 2018/18_15. pdf

11. Chatpakkarattana T, Khlaisang J. The Learner Support System for Distance Education. SciResCreative Education 2012;3(8): 47-51- DOI:10.4236/ce.2012.38b011

12. Usun S. Factors Affecting the Application of Information and Communication Technologies (ICT) in Distance Education. Turkish online journal of distance education. 2004; 5(1):1-16

13. Cheawjindakarn $B$, Suwannatthachote $P$, Theeraroungchaisri A. Critical success factors for online distance learning in higher education: A review of the literature. Creative Education. 2012;3(8B): 6166.DOI: 4236/ce.2012.38B014

14. Unwin T. ICT4D: Information and communication technology for development. (1Eds) Cambridge University Press.2009

15. Tamulienè R. Adjusting College Students' Support Services to Students' Type: Lithuania's Case. Procedia-Social and Behavioral Sciences.2014; 141: 438-446.

16. Morse J M, Hupcey J E, Mitcham C, Lenz E R. Concept analysis in nursing research: a critical appraisal. Scholarly Inquiry for Nursing Practice.1996; 10(3): 253-277

17. McKenna, H. Nursing theories and models. London and New York. Routledge. 2006.

18. Schwartz-Barcott D, Kim H S. An expansion and elaboration of the hybrid model of concept development. In B. L. Rodgers \& K. A. Knafl (Eds.), Concept development in nursing: Foundation, techniques and application (pp. 129-159). London: Saunders Concept development in nursing. 2000; (pp. 129-159).

19. Walker LO, Avant K C. Strategies for theory construction in nursing. (4 ${ }^{\text {th }}$ Eds). 2005.

20. Floyd D L, Casey-Powell D. New roles for student support services in distance learning. New directions for community colleges. 2004;(128): 55-64.

21. Gujjar AA, Naoreen B, Chaudhry AH. A comparative study of student support services: The United Kingdom, Pakistan and Sri Lanka. Procedia Social and Behavioral Sciences.2010;2: 839-846.

22. Jain P k, Salooja M K, Mythili G. An Analytical Study of Web Support in Distance Education programmer. Indian Journal of Open Learning. 2016;25(3): 187-203.

23. Sahoo P K. Unit 1: Learner Support: A Systems Approach. IGNOU.2018. http:// egyankosh.ac.in// handle/123456789/41705

24. Tait A. Planning student support for open and distance learning. Open Learning: The Journal of Open, Distance and e-Learning. 2000;15(3): 287-299.

25. LaPadula M. (2003). A comprehensive look at online student support services for distance learners. The American Journal of Distance Education.2003; 17(2): 119-128.

26. Darojat O. Sunarsih D. Learner Support Services: Policies and Implementation at Universitas Terbuka, Indonesia. ASEAN Journal of Open Distance Learning. 2014;6(1):1-20.

27. Nurmukhametov N, Temirova A, Bekzhanova The Problems of Development of Distance Education in Kazakhstan. Procedia - Social and Behavioral Sciences.2015; 182:15 - 19. 
28. Lu P, Luo L. An Analysis of Learning Efficiency Affecting Factors in Open Education Learners. Proceedings of the 2017 International Conference on Humanities Science, Management and Education Technology (HSMET 2017). Feb. Atlantis Press;2017 https://dx.doi.org/10.2991/hsmet17.2017.176

29. Sánchez-Elvira Paniagua A, Simpson O. Developing student support for open and distance learning: The EMPOWER project. Journal of Interactive Media in Education. 2018;1(9):1-10.

30. Dey F, Cruzvergara C Y. Evolution of career services in higher education. New directions for student services. 2014;(148): 5-18. https://doi.org/10.1002/ss.20105

31. Hayden S C, Ledwith K E. Career services in university external relations. New Directions for Student Services, 2014;(148): 81-92.

32. Smith K K. Strategic Directions for Career Services Within the University Setting: New Directions for Student Services: No. 148. (Ed). San Francisco, CA: Jossey-Bass.2014.

33. Mir Design and development of online student support system. Pakistan Journal of Distance \& Online Learning. 2017;3(1): 1-8.

34. Kelkar D. Creating Possibilities: An Examination of University Career Support Services for International Students in British Columbia. [dissertation]. Faculty of Arts and Social Sciences. 2016.

35. Young M. Career Services: Roles beyond Job Seeking. Education for Employability. 2019:2: 179-188. DOI: 9789004418707_015

36. Lehtinen E, Hakkarainen K, Lipponen L, Rahikainen M, Muukkonen H. Computer supported collaborative learning: A review. The JHGI Giesbers reports on education.1999: 10.

37. Farajollahi M, Moenikia M. The study of relation between students support services and distance students' academic achievement. Procedia-Social and Behavioral Sciences.2010; 2(2): 4451-4456.

38. Lee Y, Choi J, Kim Discriminating factors between completers of and dropouts from online learning courses. British Journal of Educational Technology.2013; 44(2): 328-337.

39. Stewart B L, Goodson C E, Miertschin S L, Norwood M L, Ezell S. Online student support services: A case based on quality frameworks. Merlot Journal of Online Learning and Teaching. 2013; 9(2): 290303.

40. Newberry R. Building a foundation for success through student services for online learners. Journal of Asynchronous Learning Networks. 2013; 17(4):1-15.

41. Pullan M. Online support services for undergraduate millennial students. Information Systems Education Journal (ISEDJ). 2011;9(1), 67-98.

42. Hunte S. First time online learners' perceptions of support services provided. Turkish Online Journal of Distance Education. 2012;13(2), 180-197.

43. Noviyanti M, Sudarwo R, Mardiana A, Budima M H. The Importance-performance analysis (IPA) on academic and non- academic services to enhances student motivation. Online Journal of Distance Education and e-Learning.2018; 6(1):78-88. 
44. Gregori EB, Zhang J, Galván-Fernándezc C, Fernández-Navarrod F A. Learner support in MOOCs: Identifying variables linked to completion. Computers \& Education. 2018:122; 153-168.

45. Tuquero A Meta-Ethnographic Synthesis of Support Services in Distance Learning Programs. Journal of Information Technology Education: Innovations in Practice. 2011; 10:157-179. https://doi.org/10.28945/1501

46. Ciobanu, A. The role of student services in the improving of student experience in higher education. Procedia-Social and Behavioral Sciences. 2013;92: 169-173.

47. Nsamba A, Makoe M. Evaluating Quality of Students' Support Services in Open Distance Learning. Turkish Online Journal of Distance Education.2017;18(4):91-103.

48. Sewart D. Student support systems in distance education. Open Learning: The Journal of Open, Distance and e-Learning. 1993; 8(3):3-12.

49. Potter Beyond Access: Student Perspectives on Support Service Needs in Distance Learning. Canadian Journal of University Continuing Education. 1998:24(1):59-82.

50. Brindley J E. Learner support in online distance education: essential and evolving. Online distance education. Towards a research agenda. 2014:287-310.

51. Rangara TA. Assessing learner support services rendered to undergraduate students at selected distance learning institutions. [dissertation]. University of South Africa. 2015.

52. McLoughlin C. Learner Support in Distance and Networked Learning Environments: Ten Dimensions for Successful Design. Distance Education. 2002; 23(2):149-162.

53. Allen I E, \& Seaman J. Class Differences: Online Education in the United States, 2010. Sloan Consortium (NJ1).2010.

54. Wright K B, Rosenberg J, Egbert N, Ploeger N A, Bernard D R, King S. Communication competence, social support, and depression among college students: A model of Facebook and face-to-face support network influence. Journal of health communication. 2013;18(1), 41-57.

55. Thorpe M. Rethinking learner support: The challenge of collaborative online learning. Open Learning: The Journal of Open, Distance and e-Learning. 2002; 17(2): 105-119.

56. Gorder L M. A study of teacher perceptions of instructional technology integration in the classroom. Delta Pi Epsilon Journal. 2008; 50(2): 63-76.

57. Athiyaman A. Linking student satisfaction and service quality perceptions: the case of university education. European journal of marketing. 1997; 31(7): 528-540.

58. Ali F, Zhou Y, Hussain K, Nair P K. Ragavan N A. Does higher education service quality effect student satisfaction, image and loyalty? A study of international students in Malaysian public universities. Quality Assurance in Education. 2016; 24(1):70-94.

59. Joseph M, Joseph B. Service quality in education: a student perspective. Quality assurance in education.1997; 5(1): 15-21.

60. Astin AW, Vogelgesang L J, lkeda E K, Yee JA. How service learning affects students. Los Angeles, CA: Higher Education Research Institute, UCLA. 2000 
61. Räisänen C, Fortanet-Gómez I. The state of ESP teaching and learning in Western European higher education after Bologna. ESP in European higher education: Integrating language and content. 2008; 4: 11-51. https://doi.org/10.1075/aals.4.03rai

62. Eagle L, Brennan R. Are students customers? TQM and marketing perspectives. Quality assurance in education.2007; 15(1): 44-60. https://doi.org/10.1108/09684880710723025.

63. Kochhar S K. Guidance and counselling in colleges and universities. Sterling Publishers Pvt. Ltd.1984.

64. Shernoff D J. Optimal learning environments to promote student engagement. New York, NY: Springer. 2013.

65. Jun J S. Understanding the factors of adult learners dropping out of E-learning courses. Adult Education Research Conference.2004. https://newprairiepress .org/aerc/ 2004/ papers/44.

66. Dalbani H. Autonomy in distance English language learning. Damascus University Journal.2009; 24(3+4):81-117.

67. Wagner N, Hassanein K, Head M. Who is responsible for e-learning success in higher education? A stakeholders' analysis. Journal of Educational Technology \& Society. 2008; 11(3): 26-36.

68. Adelman, C. The Bologna Process for US Eyes: Re-learning Higher Education in the Age of Convergence. Institute for Higher Education Policy.2009. https://files.eric.ed.gov/ fulltext/ED504904.pdf

\section{Figures}




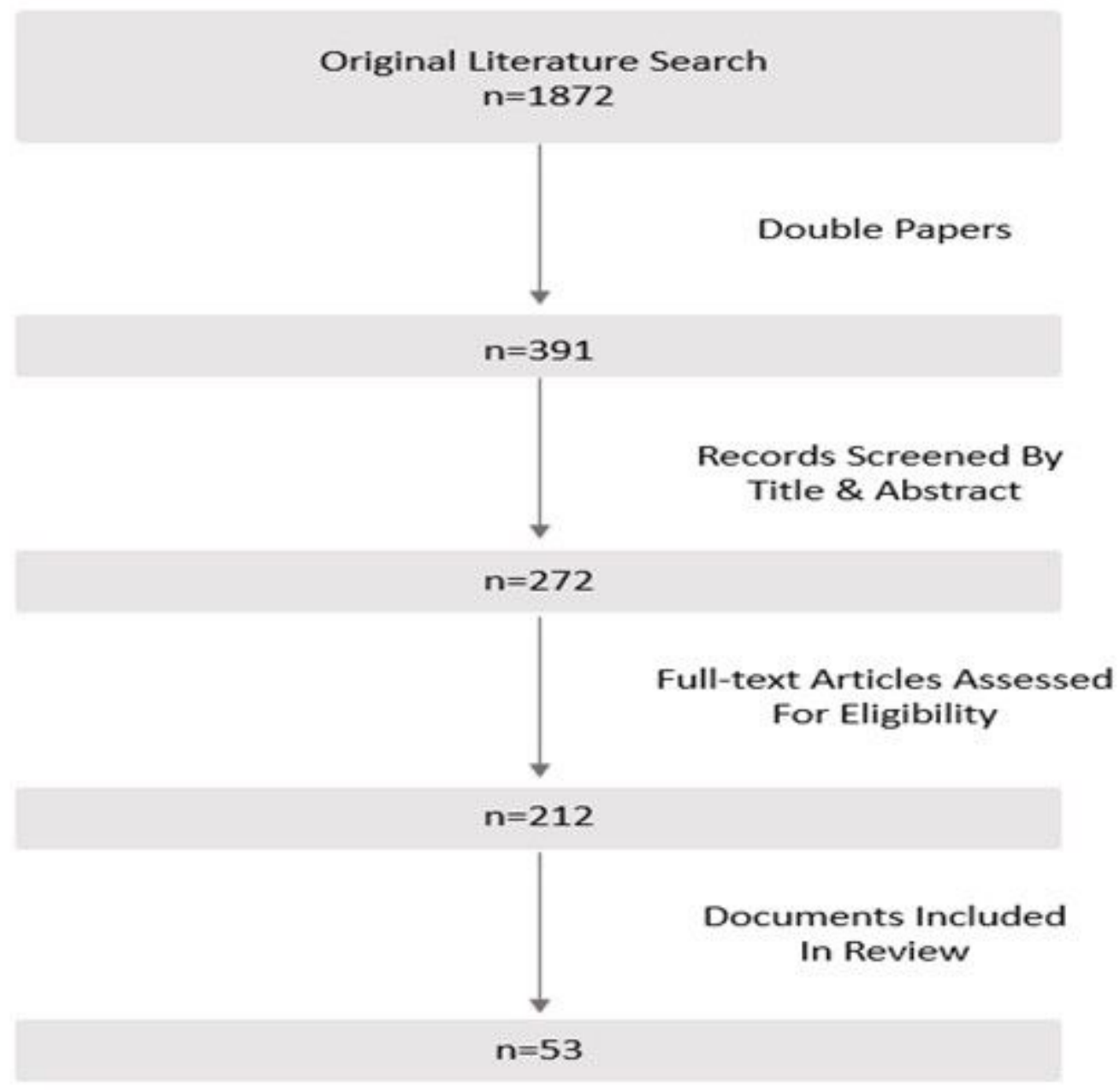

Figure 1

shows the search process and inclusion of papers in this review. 
- Selecting a suitable concept for concept analysis onset

1 -In this step, we answer the question "what are the elements and structures of student support concept?"

-Determining and defining the purpose of concept analysis

2 -At this step, the aim is to explain the elements and structures of the student support concept.

- Identifying and specifying the meaning of the concept

3 - In this step, the fields that include student support concept were identified

-Determining the attributes that define the concept

4 -After reviewing the fields related to the student support concept, new classification establish.

-Identifying and implementing a model case

5 -A model is a pure example that the student support concept is used in it and should have all the features of the concept.

-Identifying and implementing a variety of cases such as contrary, borderline, related, invented,

$6 \quad$ illegitimate and false cases

-Alternative cases include examples of what is not the student support concept.

-Identification of antecedents and consequences of the concept

7 - In this step, the analysis of the field is used.

- Noticing contexts and values

8 -concepts have different meanings based on the context . Therefore the role of student support in every country relates to context and values.

9 - Identification and designation of the empirical indicators of the concept

- This step is considered as the operationalization of student support concept

\section{Figure 2}

Hugh McKenna's nine-step method for concept analysis. 


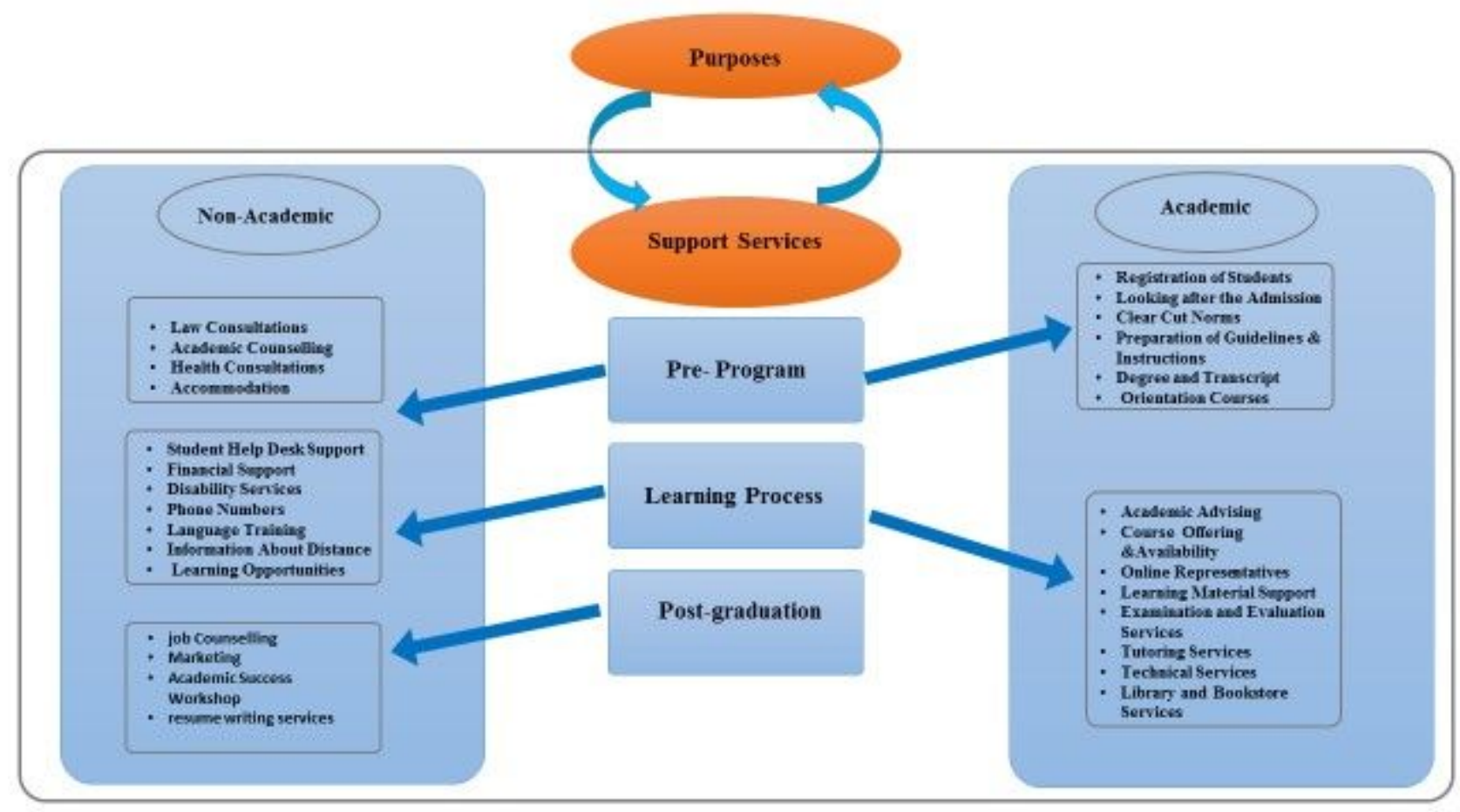

Figure 3

Student Supportive Service in blended learning: Levels, Dimensions and purposes 